Revue d'histoire de l'enfance « irrégulière »

Le Temps de l'histoire

5 | 2003

Pratiques éducatives et systèmes judiciaires

\title{
Anne-Marie Sohn " Age tendre et tête de bois. Histoire des jeunes des années 1960 »
}

Paris, Hachette Littératures, 2001, 431 p.

Dominique Dessertine

\section{OpenEdition}

Journals

Édition électronique

URL : http://journals.openedition.org/rhei/94

DOI : 10.4000/rhei.94

ISBN : 978-2-7535-1643-4

ISSN : $1777-540 \mathrm{X}$

Éditeur

Presses universitaires de Rennes

Édition imprimée

Date de publication : 15 novembre 2003

Pagination : 275

ISSN : 1287-2431

\section{Référence électronique}

Dominique Dessertine, « Anne-Marie Sohn « Age tendre et tête de bois. Histoire des jeunes des années 1960 » », Revue d'histoire de l'enfance « irrégulière » [En ligne], 5 | 2003, mis en ligne le 16 janvier 2004 consulté le 04 décembre 2020. URL : http://journals.openedition.org/rhei/94 ; DOI : https://doi.org/ 10.4000/rhei.94 


\section{Anne-Marie Sohn \\ Age tendre et tête de bois. Histoire des jeunes des années 1960 \\ Paris, Hachette Littératures, 2001, 431 p.}

On connaissait déjà Anne-Marie Sohn pour Chrysalides. Femmes dans la vie privée (XIXème-XXème siècles), issu de sa thèse d'histoire et $D u$ premier baiser à l'alcôve. La sexualité des Français au quotidien (1850-1950). Plutôt qu'une histoire des jeunes, l'auteur brosse ici un autoportrait de la jeunesse dessiné à partir de deux sources massives, l'enquête sur la jeunesse de 1966 demandée par le secrétaire d’État à la Jeunesse et aux Sports et la correspondance reçue par Ménie Grégoire lors de son émission à RTL entre 1967 à 1969.

Des quelque deux mille dossiers et lettres qu'elle a retenus pour son analyse, l'auteure, restant toujours au plus près de ses sources et de la parole des jeunes, dégage les grandes caractéristiques d'un groupe d'âge qui, pour la première fois dans les sociétés occidentales, prend conscience de sa force sociale. C'est la période où le mot "jeune" se fait substantif, où, avec mai 1968, s'exprime la génération du baby-boom.

Des sept chapitres, qui touchent autant au devenir professionnel qu'à l'épanouissement amoureux et au fossé entre les générations, on pourra s'arrêter sur le sixième qui met "Jeunes et adultes face à face " et qui aborde le phénomène "blousons noirs" ou "yéyé", bref les figures menaçantes de la jeunesse, qui permettront au lecteur d'aujourd'hui de faire la part de la construction médiatique et de la réalité, des fantasmes et des situations vécues. L'auteur parle du « face-à-face en pleine recomposition des parents et des enfants " des années 1960, relativisant un fossé que d'aucuns croyaient infranchissable. Le fourmillement des citations permet de disposer d'un gros dossier et d'éléments de comparaison avec la situation actuelle.

Dominique Dessertine Ingénieure au CNRS

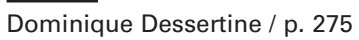

